\title{
The effectiveness of various cultivation technologies in the production of winter wheat and soybeans
}

\author{
S. Smurov*, O. Grigorov, S. Zyuba, O. Gapienko \\ Belgorod State Agricultural University named after V. Gorin, Mayskiy, Belgorod region, Russia
}

\begin{abstract}
Experimented in Belgorod State University of Agriculture in 2009-2020 years researches was focused on the effectiveness of different technologies of growing field crops based both on recommendations contained in a collection of industry regulations, "Organizational and technological norm of growing agricultural crops in the Belgorod region" (2006 and 2014) [1, 2], and on the principles of No-Till. According to the results, yield for both technologies was almost identical in our conditions. The content of gluten in the grain of winter wheat and its quality also did not differ from the cultivation technologies. The same dependence on yield and protein content was also shown in soybean cultivation. Economic efficiency was higher by minimal technology.
\end{abstract}

\section{Introduction}

The key direction in the development of agricultural production in Belgorod Oblast and Russia as a whole remains the increase in gross grain output, primarily due to higher yields. One of the most important tasks of the agro-industrial complex is the development of cattle breeding, the growth of pork and poultry meat production. In this regard, it is necessary to implement a system of effective measures to improve the fodder base on the basis of development of biological farming and soil-saving technologies. [3, 4]

Modern biological farming system is aimed at obtaining high yields with improved quality indicators of crop production, subject to the mandatory condition of sufficient profitability of agribusiness as a whole, which is achieved through [6,7]:

- restoration of natural soil fertility with elements of soil treatment;

- crop residue management, in order to effectively use crop residues as scarce organic matter, as well as to reduce the dynamics of disease spreading on new crops;

- reduction of pesticide load in general, the use of combined, i.e. chemical and biological protection of plants against diseases, including new complex root rots, bacterioses, viroses, mycoplasmosis;

- introduction and successful adaptation of energy-saving technologies with minimum soil tillage (Mini-Till) and with complete abandonment of soil tillage (No-Till).

As a counterbalance to the traditional system of farming with the use of mouldboard ploughing, scientists and practitioners have proposed a minimum tillage technology. The

*Corresponding author: smurov_si@bsaa.edu.ru 
Mini-Till system, based on reducing the depth and number of mechanical cultivation, involves the use of disc and flat-cut tillage tools and promotes the rational use of rainfall, especially in arid areas, reduction of humus mineralization, lower energy consumption, which ultimately provides a high soil-protective effect against water and wind erosion. At the same time, labor productivity increases due to the use of wide-cut machines and implements, and the mobility of technological operations increases significantly $[1,2,5,8]$.

Minimum tillage technology based on the use of combined machines has a positive effect on the reduction of energy costs by reducing the number and depth of tillage, combining mechanical operations and application of chemicals in one unit [10].

German scientist Prof. K. Kelner highlighted several reasons why agricultural producers should switch from conventional agriculture to conservation agriculture. Resource-saving methods of tillage have many advantages, in particular, saving (fuel, human and machine labor) and reducing harm to the environment. At the same time, agricultural producers should be aware that switching from conventional ploughing can be difficult and equipment is expensive. In addition, herbicide costs increase and yields may be reduced at first. [8]

The theoretical advantages of new technologies are:

- increased profitability;

- reduction of diesel fuel costs;

- moisture retention;

- humus conservation;

- erosion prevention;

- reduction of capital and labour costs;

- Increased opportunities for consecutive sowing of different crops. [11]

The No-Till system is part of a larger, evolving vision of self-replicating agriculture, in which a variety of methods from No-Till to organic and combinations of both are considered correct and necessary. [1, 2, 10, 12].

Therefore, the study of different technologies is a very topical issue for modern agricultural science. The solution of this problem will increase the profitability of agricultural production by introducing the optimal technology in terms of productivity and profitability of cultivated crops, conservation and reproduction of soil fertility.

\section{Objects and methods}

This problem was studied in the stationary experiment of the laboratory of the Belgorod State Agrarian University's cropping systems research, which was laid in 2008 in the four-field crop rotations with the following alternation of cultures: 1 field - soybean, 2 field - winter wheat, 3 field - row crops (corn for grain, sunflower), 4 field - spring barley.

According to the technology with shallow mulching of soil, the agrotechnics of care for the studied crops was based on observations of the state of the arable land and crops and, if necessary, included for the creation and maintenance of soil mulch periodic without ploughing (discs or cultivator) of arable layer to a depth of 14-16 cm for spring crops and to 4-6 cm for winter ones, treatment of plots with herbicides, insecticides and fungicides. Seeders with disc coulters (SZ-3,6 and Semeato SHM 15/17) were used for sowing cereal crops. The main fertilizer application was carried out with their embedding in the soil to a depth of 5-6 $\mathrm{cm}$ by SZ-3,6 seeder.

The second technology included post-harvest treatment of the fields with general herbicides, surface application of the main dose of fertilizers, direct seeding of crops and their spraying during the growing season with pesticides as needed. From 2008 to 2011, the crops were used a drill "Burgo" with anchor coulters, and since 2012, the crops were sown by a specialized disc seeder SHM 15/17 SEMEATO. Another difference of No-Till 
technology from Mini-Till technology was that after the crops, the crops were sown in the form of white mustard.

\section{Research results and their discussion}

The soil of the experimental plots refers to typical, medium-powered, medium-loam on loesslike loam. As a result of agrochemical examination of soils in 2017, it was found that after ten years of experiment using the minimum technology in the layer $0-40 \mathrm{~cm}$ on average across the fields contained hydrolyzable nitrogen $158 \mathrm{mg} / \mathrm{kg}$, mobile phosphorus $156 \mathrm{mg} / \mathrm{kg}$, and the amount of exchangeable potassium was at $133 \mathrm{mg} / \mathrm{kg}$. In no-till fields, the amount of macronutrients was $160 \mathrm{mg} / \mathrm{kg}, 152 \mathrm{mg} / \mathrm{kg}$ and $141 \mathrm{mg} / \mathrm{kg}$, respectively. The degree of acidity and humus content in both technologies were close. Thus, at Mini-Till the $\mathrm{pH}$ was 6.0 units, at No-Till it was 5.7 units and the humus content was $4.9 \%$ and $5.0 \%$ respectively.

Analyzing the data we can conclude that the application of No-Till technology did not change the content of nitrogen and phosphorus in the soil relative to the minimum, but the amount of exchangeable potassium increased by $8 \mathrm{mg} / \mathrm{kg}$. Soil acidity was closer to neutral under the Mini-Till technology, while under the No-Till technology insignificant acidification was observed due to the fact that fertilizers were spread on the soil surface during basic fertilization and in its upper layer accumulation of elements contributing to this process was observed due to their low mobility. Farming on the basis of No-Till principles led to positive trend of humus content accumulation in comparison with the technology using Mini-Till.

To determine the reserves of productive moisture and soil density under the studied crops, soil samples were taken annually before sowing and harvesting. Average data on these indicators for the period from 2009 to 2020 inclusive are given in Tables 1 and 2 .

Table 1. Productive moisture stocks under different field cropping technologies (average for 2009-2020), $\mathrm{mm}$.

\begin{tabular}{|c|c|c|c|c|c|}
\hline \multirow{2}{*}{ Cultures } & \multirow{2}{*}{$\begin{array}{c}\text { Cultivation } \\
\text { technology }\end{array}$} & \multicolumn{2}{|c|}{ At the time of sowing. } & \multicolumn{2}{|c|}{$\begin{array}{c}\text { For the duration of the } \\
\text { cleanup. }\end{array}$} \\
\cline { 3 - 6 } & & \multicolumn{4}{|c|}{ Soil layer, cm } \\
\cline { 3 - 6 } & & $0-30$ & $0-100$ & $0-30$ & $0-100$ \\
\hline \multirow{2}{*}{ Soybean* } & Mini-Till & 46 & 171 & 17 & 68 \\
\cline { 3 - 6 } & No-Till & 47 & 181 & 20 & 71 \\
\hline \multirow{2}{*}{$\begin{array}{c}\text { Winter } \\
\text { wheat }\end{array}$} & Mini-Till & 19 & 78 & 28 & 88 \\
\cline { 2 - 6 } & No-Till & 23 & 89 & 30 & 91 \\
\hline
\end{tabular}

* - the average for 2010, 2011, 2014-2020 was calculated.

When growing soybean, the use of No-Till technology generally contributed to the accumulation of more productive moisture in the $0-100 \mathrm{~cm}$ layer by the time of sowing the crop relative to the minimum. On average over nine years when using No-Till this layer contained $10 \mathrm{~mm}$ more moisture than under Mini-Till. But by harvest time the available moisture in the soil was kept almost the same, $68-71 \mathrm{~mm}$ each. In the layer $0-30 \mathrm{~cm}$ at the time of sowing soybean moisture reserves in the soil were the same $-46 \mathrm{~mm}$ and $47 \mathrm{~mm}$ respectively technologies, and by harvesting their difference was $3 \mathrm{~mm}$ in favor of the technology without mechanical tillage.

On average for the years of research before sowing of winter wheat stocks of productive moisture in the $0-30 \mathrm{~cm}$ layer were $4 \mathrm{~mm}$ less when using the technology with shallow tillage relative to No-Till, and in the $0-100 \mathrm{~cm}$ layer this difference increased to $11 \mathrm{~mm}$. At the time 
of harvesting the differences between the technologies in terms of available moisture reserves decreased to $2-3 \mathrm{~mm}$.

It should be noted that in the first two years of research during sowing of winter wheat the amount of productive moisture in the meter soil layer was higher at minimum tillage by 6-11 $\mathrm{mm}$, and in other years at no-till, and depending on weather conditions, these exceedances were from $4 \mathrm{~mm}$ to $27 \mathrm{~mm}$. In the $0-30 \mathrm{~cm}$ soil layer such a clear pattern was not observed, but out of eleven years of the experiment only four years of available moisture stocks under No-Till were slightly (no more than $2 \mathrm{~mm}$ ) lower than under the shallow tillage technology.

The study of soil compaction density showed that, on average, there were no differences in this indicator between the technologies before sowing soybeans in all years of research (Table 2).

Table 2. Effect of cultivation technologies on tilled layer density in field crops (average for 2009-2020), g/ $\mathrm{cm}^{3}$.

\begin{tabular}{|c|c|c|c|c|c|c|c|}
\hline \multirow{3}{*}{ Cultures } & \multirow{3}{*}{$\begin{array}{l}\text { Cultivation } \\
\text { technology }\end{array}$} & \multicolumn{3}{|c|}{ At the time of sowing. } & \multicolumn{3}{|c|}{ For the duration of the cleanup. } \\
\hline & & \multicolumn{6}{|c|}{ Soil layer, $\mathrm{cm}$} \\
\hline & & $0-15$ & $15-30$ & $0-30$ & $0-15$ & $15-30$ & $0-30$ \\
\hline \multirow{2}{*}{ Soybean* } & Mini-Till & 0,99 & 1,05 & 1,02 & 0,96 & 1,03 & 1,00 \\
\hline & No-Till & 0,99 & 1,06 & 1,03 & 0,98 & 1,01 & 1,00 \\
\hline \multirow{2}{*}{$\begin{array}{l}\text { Winter } \\
\text { wheat }\end{array}$} & Mini-Till & 0,99 & 1,06 & 1,03 & 1,00 & 1,09 & 1,06 \\
\hline & No-Till & 1,04 & 1,10 & 1,07 & 1,06 & 1,11 & 1,08 \\
\hline
\end{tabular}

* - the average for 2010, 2011, 2014-2020 was calculated.

Thus, in $0-15 \mathrm{~cm}$ layer soil density was $0.99 \mathrm{~g} / \mathrm{cm}^{3}$ by both technologies, at a depth of 15 $\mathrm{cm}$ to $30 \mathrm{~cm}$ it was $1.05 \mathrm{~g} / \mathrm{cm}$ by Mini-Till ${ }^{3}$ and $1.06 \mathrm{~g} / \mathrm{cm}^{3}$ by No-Till, and in average in thirty-centimeter layer it was $1.02 \mathrm{~g} / \mathrm{cm}^{3}$ and $1.03 \mathrm{~g} / \mathrm{cm}$ by technologies respectively. ${ }^{3}$

By the time of soybean harvesting using Mini-Till technology the soil in 0-15 cm layer became less dense, and at zero tillage practically did not change. At the depth of $15-30 \mathrm{~cm}$ soil density was at the level of $1.03-1.01 \mathrm{~g} / \mathrm{cm}^{3}$, and in the whole investigated layer it was the same and was $1.00 \mathrm{~g} / \mathrm{cm}^{3}$.

Before sowing of winter wheat average soil density for twelve years in $0-15 \mathrm{~cm}$ layer was $0.99 \mathrm{~g} / \mathrm{sm}^{3}$ for minimum technology and $1.04 \mathrm{~g} / \mathrm{sm}^{3}$ for no-till technology (Table 2). It increased with increasing depth and in layer $15-30 \mathrm{~cm}$ it was $1.06 \mathrm{~g} / \mathrm{cm}^{3}$ and $1.10 \mathrm{~g} / \mathrm{cm}$ ${ }^{3}$ respectively for technologies. On average, 0-30 cm layer, using shallow tillage was slightly less dense than the crop without mechanical loosening, $1.03 \mathrm{~g} / \mathrm{cm}^{3} \mathrm{vs} .1 .07 \mathrm{~g} / \mathrm{cm}^{3}$.

By the time of winter wheat harvesting soil density increased by both technologies, except for the upper layer of Mini-Till technology, where this indicator remained close to the level at the time of sowing. As well as in autumn by Mini-Till technology the values of density indices in $0-30 \mathrm{~cm}$ layer were lower relative to values by No-Till technology. It should be noted that with increasing the depth of sampling the difference between them decreased, and on average in the layer $0-30 \mathrm{~cm}$ for the technology with shallow loosening of the soil it was equal to $1.06 \mathrm{~g} / \mathrm{cm}^{3}$ and $1.08 \mathrm{~g} / \mathrm{cm}^{3}$ for No-Till.

Thus, although soil density had small differences in its parameters depending on the technology used, but it was always within the optimal agronomic limits required for growing soybean and winter wheat by both technologies.

Based on the yield data obtained during the study period, which exceeded two rotations of crop rotation, it can be argued that the use of such technology as No-Till did not lead to a significant change in the level of yield of crops studied in the experiment compared to the Mini-Till technology (Table 3 and 4). 
Table 3. Effect of cultivation technologies on soybean yields, $\mathrm{t} / \mathrm{ha}$.

\begin{tabular}{|c|c|c|c|c|c|c|c|c|c|c|c|}
\hline Cultivation & \multicolumn{10}{|c|}{ Years of research } & \multirow{2}{*}{$\begin{array}{c}\text { Average } \\
\text { by year }\end{array}$} \\
\cline { 2 - 13 } \\
technology & 2009 & 2010 & 2011 & 2014 & 2015 & 2016 & 2017 & 2018 & 2019 & 2020 & 2,3 \\
\hline Mini-Till & 1,61 & 1,34 & 1,70 & 2,81 & 2,59 & 3,39 & 2,08 & 3,21 & 2,22 & 2,36 & 2,33 \\
\hline No-Till & 1,42 & 1,17 & 1,51 & 2,33 & 2,44 & 3,17 & 1,79 & 2,99 & 2,19 & 2,12 & 2,11 \\
\hline $\begin{array}{c} \pm \text { No-Till to } \\
\text { Mini-Till }\end{array}$ & $-0,19$ & $-0,17$ & $-0,19$ & $-0,48$ & $-0,15$ & $-0,22$ & $-0,29$ & $-0,22$ & $-0,03$ & $-0,24$ & $-0,22$ \\
\hline NSR $_{05}$ & 0,21 & 0,22 & 0,21 & 0,33 & 0,14 & 0,25 & 0,14 & 0,29 & 0,21 & 0,21 & 0,22 \\
\hline
\end{tabular}

Table 4. Effect of cultivation technologies on winter wheat yields, $t /$ ha.

\begin{tabular}{|c|c|c|c|c|c|c|c|c|c|c|c|c|c|}
\hline \multirow{2}{*}{$\begin{array}{c}\text { Cultivation } \\
\text { technology }\end{array}$} & \multicolumn{10}{|c|}{ Years of research } & $\begin{array}{c}\text { Average } \\
\text { by year }\end{array}$ \\
\cline { 2 - 15 } & 2009 & 2010 & 2011 & 2012 & 2013 & 2014 & 2015 & 2016 & 2017 & 2018 & 2019 & 2020 & \\
\hline Mini-Till & 6,01 & 2,36 & 4,08 & 2,86 & 3,09 & 6,15 & 5,99 & 5,76 & 7,84 & 6,40 & 5,71 & 7,60 & 5,32 \\
\hline No-Till & 5,96 & 2,61 & 3,78 & 2,78 & 2,84 & 5,90 & 5,72 & 6,31 & 7,68 & 6,62 & 5,57 & 7,46 & 5,27 \\
\hline $\begin{array}{c} \pm \text { No-Till } \\
\text { to Mini- } \\
\text { Till }\end{array}$ & $-0,05$ & 0,25 & $-0,30$ & $-0,08$ & $-0,25$ & 0,15 & $-0,27$ & 0,55 & $-0,16$ & 0,22 & $-0,14$ & $-0,14$ & $-0,05$ \\
\hline NSR $_{05}$ & 0,44 & 0,27 & 0,33 & 0,22 & 0,37 & 0,44 & 0,30 & 0,37 & 0,55 & 0,27 & 0,21 & 0,33 & 0,34 \\
\hline
\end{tabular}

The obtained deviations in soybean grain yield in six out of ten years were of a decreasing tendency, as they were within the error of experiment, and only in four years the decrease was reliable. The average yield of soybean in the years of research was $2.11 \mathrm{t} / \mathrm{ha}$ at cultivation by no-till technology and $2.33 \mathrm{t} / \mathrm{ha}$ at cultivation by technology with minimum loosening of the soil. Thus, over the ten-year period of experience, the effectiveness of soybean productivity technologies was at the same level, with a slight advantage of its cultivation with shallow tillage.

Cultivation of winter wheat for twelve years using no-till technology showed that the yield relative to the technology with shallow tillage, depending on weather conditions could both increase and decrease (Table 4).

Eight years out of twelve, the use of No-Till gave an insignificant decrease in yield (by $0.05-0.30 \mathrm{t} / \mathrm{ha}$ ) and four years an increase, with a significant increase in 2016 (by $0.55 \mathrm{t} / \mathrm{ha}$ with $\mathrm{NSR}_{05}=0.37 \mathrm{t} / \mathrm{ha}$ ). The average winter wheat grain yield was $5.32 \mathrm{t} / \mathrm{ha}$ by Mini-Till technology and $5.27 \mathrm{t} /$ ha by no-till.

Chemical and physical analyses of grain were carried out to assess the quality of harvested crops in the experiment (Tables 5 and 6).

Table 5. Effect of cultivation technologies on physical and chemical parameters of soybean grain (average for 2014-2020).

\begin{tabular}{|c|c|c|c|}
\hline $\begin{array}{c}\text { Cultivation } \\
\text { technology }\end{array}$ & $\begin{array}{c}\text { Weight of } 1000 \\
\text { grains, } g\end{array}$ & Dry matter, $\%$ & Protein content, $\%$ \\
\hline Mini-Till & 126 & 91,2 & 39,62 \\
\hline No-Till & 119 & 91,2 & 39,37 \\
\hline
\end{tabular}

Table 6. Effect of cultivation technologies on the content and quality of "crude" gluten, class and physical indicators of winter wheat grain (average for 2009-2020).

\begin{tabular}{|c|c|c|c|c|c|}
\hline \multirow{2}{*}{$\begin{array}{l}\text { Cultivation } \\
\text { technology }\end{array}$} & \multicolumn{2}{|c|}{ "Raw" gluten } & \multirow{2}{*}{ Grain class } & \multirow{2}{*}{ Natura, g/l } & \multirow{2}{*}{$\begin{array}{l}\text { Weight of } 1000 \\
\text { grains, g }\end{array}$} \\
\hline & Content, \% & Quality Group & & & \\
\hline Mini-Till & 31,4 & 2 & 3 & 760 & 40,4 \\
\hline No-Till & 29,1 & 2 & 3 & 762 & 39,6 \\
\hline
\end{tabular}


The studies conducted in the accredited testing laboratory of the Belgorod State Agrarian University showed that the crude protein (protein) content in soybean grain was higher for the technology with shallow tillage and amounted on average to $39.62 \%$ over the last seven years of study, and $39.37 \%$ for no-till technology. The dry matter content of the grain of this valuable leguminous crop was similar and amounted to $91.2 \%$ for both technologies.

The 1000 grain weight of soybean was higher with the shallow tillage technology, 126 grams versus 119 grams with the no tillage technology. In the end, this probably led to lower grain harvest of the crop (Tables 3 and 5).

The data obtained during the study suggest that the studied technologies when used in them identical doses of mineral nutrition and the same pest control measures in the sowing of winter wheat in all years of the study gave the same quality of "raw" gluten in its grain, which was characterized as satisfactory weak. At the same time, in terms of gluten content in some years there was an advantage in one of the two technologies studied - in 2010 it was No-Till $(+4.2 \%)$, in 2014 and in 2019 Mini-Till (5.9\% and $4.2 \%$ more than by No-Till respectively). This was due to agroclimatic conditions in the period of cultivation of this crop.

On average for the years using Mini-Till technology the content of "raw" gluten in winter wheat grain was higher by $2.3 \%$ relative to zero, but this can be assessed as an insignificant excess, since the second group of quality in both methods of cultivation grain belonged to the same class. (Table 6).

The physical indicators of winter wheat grain, characterizing its fulfillment (nature and weight of 1000 grains), did not show a clear dependence on the technology of cultivation. Grain body was within 760-762 g/l, and weight of 1000 grains by Mini-Till technology was equal to 40.4 grams, and by No-Till 39.6 grams.

Economic efficiency of soybean and winter wheat production, as shown by the analysis of costs according to the technological charts of experience and prevailing in these years costs of products, fuel and lubricants and pesticides, depended on both the growing technology used and the yield of the crop (Tables 7 and 8).

Table 7. Economic efficiency of soybean production depending on the cultivation technology used (average for 2010-2011 and 2014-2020).

\begin{tabular}{|c|c|c|c|c|c|}
\hline $\begin{array}{c}\text { Cultivation } \\
\text { technology }\end{array}$ & Yield, t/ha & $\begin{array}{c}\text { Amount from sales } \\
\text { RUR/ha }\end{array}$ & Direct costs, rub./ha & Profit, rub. & Profitability, \% \\
\hline Mini-Till & 2,33 & 53229,78 & 24671,52 & 28558,26 & 115,8 \\
\hline No-Till & 2,11 & 48191,56 & 26634,82 & 21556,74 & 80,9 \\
\hline $\begin{array}{l}\text { No-Till to } \\
\text { Mini-Till }\end{array}$ & $-0,22$ & $-5038,22$ & 1963,30 & $-7001,52$ & $-34,9$ \\
\hline
\end{tabular}

Table 8. Economic efficiency of winter wheat grain production depending on applied cultivation technology (average for 2010-2020).

\begin{tabular}{|c|c|c|c|c|c|}
\hline $\begin{array}{c}\text { Cultivation } \\
\text { technology }\end{array}$ & Yield, t/ha & $\begin{array}{c}\text { Amount from } \\
\text { sales RUR/ha }\end{array}$ & $\begin{array}{c}\text { Direct costs, } \\
\text { rub./ha }\end{array}$ & Profit, rub. & Profitability, \% \\
\hline Mini-Till & 5,32 & 55173,72 & 25753,63 & 29420,09 & 114,2 \\
\hline No-Till & 5,27 & 54655,15 & 24952,35 & 29702,80 & 119,0 \\
\hline $\begin{array}{c}\text { No-Till to } \\
\text { Mini-Till }\end{array}$ & $-0,05$ & $-518,55$ & $-801,28$ & 282,71 & 4,8 \\
\hline
\end{tabular}

The value of direct operating costs was determined by the presence of differences in the methods of soil preparation for sowing the crop and weed control.

Exclusion of mechanical tillage from the technology of soybean growing when it was based on No-Till principles, led to a threefold reduction of labor costs and more than twofold reduction of consumption of fuel and lubricants per unit area of sowing. However, the number of treatments with herbicides of general destructive effect increased, which at current prices 
on them increased the cost of conducted activities compared to the mechanical destruction of the forecrop and weeds. At the same time, after barley the soybean predecessor was sown in the form of mustard white, which also led to an increase in costs. At the same time, as noted above, there was no significant increase in soybean grain yield. Therefore, the cultivation of soybeans under the No-Till system led to a decrease in the profitability of its cultivation compared to the technology with shallow loosening of the soil by almost $35 \%$.

At cultivation of winter wheat on No-Till technology there were no expenses for purchase of preparations of continuous action and on seeding of soil siderat, and yield capacity of this crop was practically at the same level with a technology with soil treatment and, therefore, profitability was higher at use No-Till on 4,8 \% which was $119,0 \%$.

\section{Conclusions}

In general, studies have shown that in the prevailing weather conditions in these years, both technologies of cultivation yielded a good winter wheat and soybean grain, and this gives reason to argue that each of them can be used in Belgorod region, and the choice of which system to work, should be determined by economic calculations and environmental factors for a particular farm.

\section{References}

1. S. N. Aleinik, Organizational and technological standards of agricultural crops cultivation in the Belgorod Oblast. Collection of sectoral regulations, 676 (Belgorod, Federal State Educational Institution of Higher Professional Education BelGKhA, 2006)

2. S. N. Aleinik. N. Aleinik, Organizational and technological standards of agricultural crops cultivation (by the example of Belgorod Oblast) 462 (Belgorod, Constanta, 2014)

3. E.V. Truflyak et al., Monitoring and forecasting of scientific and technological development of agroindustrial complex of Russia for the period up to 2030, 328 (Publishing house, LLC "Amirit" (Saratov), 2020)

4. E.S. Savchenko, Belgorod agromir, magazine on effective agriculture 2, 17-20 (2011)

5. E. S. Savchenko, Our contemporary 4, 3-11 (2012)

6. S.I. Smurov, O.V. Grigorov, D.P. Belikov, Innovations in agroindustrial complex: problems and prospects 4 (20), 152-161 (2018)

7. V. Baturin, No-Till - a step to ideal farming, 119 (Pl., tabl., Moscow, 2006) ISBN 587953245-3

8. Collection of articles on No-Till (Dnepropetrovsk, AGRO-Soyuz, 2007)

9. Free Farming: Mini-Till, Company "Agroterra" URL: https://sites.google.com/site/ striptillua mini-till

10. The main reasons for the transition of farmers to minimum and zero tillage / Ukrainian Agrarian Investments Company // URL: http://www.bakertilly.ua/ru/news/id684 (accessed 14.10.2017)

11. Carlos C. Crovetto, No-Till. Relationship between No-Till, crop residues, plant nutrition and soil (Dnepropetrovsk, Agro-Soyuz, 2007)

12. V.K. Dridiger, Farming 3, 5-9 (2016) 